\title{
INTERTEXTUALITY AS MIMESIS AND METAPHOR: THE DEVIANT PHRASEOLOGY OF CARYL PHILLIPS'S OTHELLO'
}

\author{
Jonathan P.A. Sel1 ${ }^{2}$
}

\begin{abstract}
This article considers the intertextuality of the "Othello" fragments in Caryl Phillips's The Nature of Blood in the light of theoretical characterisations of intertextuality as "deviant phraseology", "ungrammaticality" and "impropriety". Far from being merely an exercise in postmodern cut and paste or a conventional subaltern challenge to a hegemonic cultural text, the deviant phrasing of Phillips's "Othello" fragments proposes that the cognitive challenge posed by intertextuality may, by analogy with metaphor, become an exercise in intercultural empathy which, if carried out with any degree of success, may equip readers better for life in a multicultural or cosmopolitan society.

Keywords: Intertextuality, alterity, Caryl Phillips, metaphor, The Nature of Blood.
\end{abstract}

Resumen: A la luz de las caracterizaciones teóricas de la intertextualidad como "fraseología desviada", "no gramaticalidad" e "impropiedad", el presente artículo ofrece una consideración de los fragmentos "otelianos" de la novela The Nature of Blood de Caryl Phillips. Lejos de constituir un mero ejercicio posmoderno de "cortar y pegar" o una subversión "subaltern" de un hegemónico texto cultural, la fraseología desviada de dichos fragmentos plantea la posibilidad de que el reto cognitivo que supone la intertextualidad pueda convertirse en un ejercicio de empatía intercultural, la cual puede contribuir a formar a los lectores para la vida en una sociedad multicultural o cosmopolita.

Palabras clave: Intertextualidad, alteridad, Caryl Phillips, metáfora, The Nature of Blood.

\section{INTRODUCTION}

Recent investigations (Döring 2002; Kloos 1998; Nielsen 1994) of the interfaces between intertextuality and postcolonial writing have discovered ways in which writers may exploit intertextuality in order to subvert dominant discourses or to question the relevance of traditional genres to particular ethnic experiences. This article suggests that if indeed, on the mimetic level, intertextuality shows how dominant discourses and genres are inadequate to the task of representing alien subjectivity, on the semiotic level intertextuality can actually inscribe the experience of that subjectivity and, through a process of estrangement, generate

Date of reception: April 2008.

Date of acceptance and final version: July 2008.

This article is the outcome of work in progress as part of a larger research project financed by the DGI of the Spanish Ministry of Science and Technology under the title "Metáforas de la diáspora postcolonial en la Gran Bretaña de finales de siglo (1990-2005)" (code: HUM2007-63028/FILO).

2 Lecturer, Departamento de Filologías Modernas, Universidad de Alcalá; $₫$ jonathan.sell@uah.es. 
in the reader a replica of it. ${ }^{3}$ If we accept Derrida's notion of écriture as extending to the writing or written-ness of the subject's identity, the rhetoric of that writing or written-ness becomes a legitimate object of study. Intertextuality (as semiotic process and result) and within intertextuality allusion (as the conscious manipulation of intertexts) are a major part of that rhetoric. ${ }^{4}$ Derrida (1978: 131) claimed that otherness lay intrinsically beyond our grasp, that "an experience which could not be lived as my own" was "impossible and unthinkable". This article will demonstrate that, on the contrary, far from leaving readers with so many parcels of sophisticated textuality on their hands which inevitably occlude the subjectivity of others, intertextuality bridges the experiential and cognitive gaps that separate disparate subjects and thus enables fictions to achieve their goal of building empathy between reader and character.

At first sight allusion appears to be a particularly potent resource for those wishing to stake a claim to membership of a linguistic community, whether as ordinary users of the host society's language or as aspirants to literary success. Through lending an utterance or text authority and signalling its producer as culturally clued-in, allusion smooths an outsider's passage towards acceptance by insiders (Sell 2004); indeed, its deployment with the conscious goal of winning social acceptance is something of a commonplace in Extravagant Strangers, Caryl Phillips's anthology of arrival narratives. ${ }^{5}$ The pragmatic use by transcultural subjects of intercultural allusion in the presentation of identities palatable to the host society might not surprise structuralists, who would readily claim that the transcultural subject in the process of passing from one culture/society/polity to another is, in so far as between cultures, between texts too and therefore literally intertextual. Yet it will be immediately obvious that allusion may also be an agent of estrangement if the outsider's references are to a textual universe beyond the ken of the insiders he is addressing; such estrangement will lead either to rejection of the outsider on the part of the insider or to an awareness that there is much learning to be done in order to grasp fully where the outsider is coming from and thence to embrace him as a brother. The latter is often the one sideeffect of the intertextual stereophony of Salman Rushdie's novels where few readers are sufficiently familiar with both Rushdie's English and Indian allusive frameworks to avoid being estranged by one or the other (Sell 2000). However, the contrivance of estrangement may yield a beneficial cognitive and empathetic dividend since it highlights the culture gap

\footnotetext{
Of course, any talk of a/the "reader" or of "readers" is open to the charge of wild generalisation. In this article, by "reader" or "readers" I refer to those who, because of their own experiential biographies, take Phillips's Othello to be a alien, strange or foreign.

4 To clarify my argument, I use "intertextuality" to refer to "the transposition of one or more systems of signs into another" (Roudiez 1984: 15) and to the polyvocal discursive-communicative space derived from such transpositions; in other words, "intertextuality" is both semiotic process and socio-cultural result or "sociocultural condition" in so much as, just like the Kristevan text, at a given moment in time a society or culture is a "productivity ... a permutation of texts, an intertextuality" (Kristeva 1984: 36); or, like the Barthesian text, it is a "multi-dimensional space in which a variety of writings, none of them original, blend and clash" (Barthes 1988: 156). In contrast, when referring to the conscious intertextual procedure of those quoting from, citing or alluding to the words of others, I shall use the term "allusion" thereby upgrading the subject's autonomy in playing the intertext. If Roland Barthes (1976: 36) argued that the intertext is "What comes to me, not what I summon up", it is that summoning up that I understand as allusion. But the divorce between intertextuality and allusion is not complete since any act of allusion is another transposition which transforms the intertext itself.

5 See the extracts from C. L. R. James and Shiva Naipaul (Phillips 1997: 62-70, 187-95).
} 
which the outsider is forced to bridge at the same time as it reflects the outsider's own sensation of permanent strangeness inside a foreign culture. Estrangement may thus enlighten the insider vis-à-vis the outsider's subjectivity on the intellectual and emotional planes.

For the purposes of this study, I have chosen to consider intertextuality and its effects in Caryl Phillips's The Nature of Blood (1997). This is for two reasons: firstly, however uncomfortably, the novel wears its intertextuality on its sleeve; secondly, it is the novel's intertextual episodes, especially the "Othello" fragment, which linger longest in the reader's mind while generating qualms regarding the novel's formal cohesion. Put bluntly, the relationship between the "Othello" fragment, the lesser, Portobuffole fragment and the (apparently) main holocaust plot (which takes us from Nazi concentration camp to modern Israel) is at best too subtle for most readers to identify, at worst padding for a slender novel -albeit such padding may, under the benign aesthetic dispensations of postmodernism, be condoned as a metafictional demonstration of the interconnectedness of history and fiction. ${ }^{6}$ In what follows I shall try to make a case for Phillips's intertextual procedure as being deliberately and constantly estranging in different ways. An appraisal of just how profitable that procedure is shall be left for Section 4. Section 3 will be occupied with an analysis of some episodes in Phillips's intertextual procedure, an analysis undertaken after some consideration of the analogies between intertextuality and identity, the subject of Section 2 .

\section{INTERTEXTUALITY AND ALTERITY}

There are some suggestive analogies between intertextuality and the foreigner or outsider. Firstly, according to Riffaterre (1980: 84), the intertextual is intrinsically a dual sign on account of its simultaneous sitedness in two different contexts, the quotation text (the text where the intertextual reference is made) and the pre-text (the text to which that reference is owed) $;{ }^{7}$ and this dual sitedness problematises interpretation, for the intertextual fragment refuses to commit itself to any referential allegiance to one context or the other. Here the analogy would be with the ambivalent condition of the transcultural subject, who may unabashedly declare, for example, dual sitedness by holding two passports -as does Caryl Phillips (St. Kitts and United Kingdom) (Bell 1991: 593)- and whose allegiances may be questioned by the likes of Norman Tebbit when caught cheering on the wrong side at cricket. Secondly, Linda Hutcheon (1991) has pointed out how, in political terms, intertextuality has been viewed as fundamentally subversive of representational canons and, more generally, of society at large. Similarly, the outsider causes us to rethink our own self-representations before either expansively modifying or defensively reasserting them, our modification or reassertion depending on whether we see immigration as an opportunity or threat to ourselves and to society at large. Thirdly, much as intertextuality is a transposition of one text to another which leads to the latter's transformation, ${ }^{8}$ so the

\footnotetext{
6 See Ledent (2002: 165-73) for an interesting appraisal of Phillips's postmodernist credentials, the main point of which is that "Caribbean societies, with their fragmented histories and archipelagan geographies, were postmodern avant la lettre" (171).

7 Although Riffaterre provides the main theoretical inspiration for this article, I prefer the term "pre-text" to his "intertext" and shall be using it throughout.

8 See above, n. 3.
} 
arrival of foreign subjects always transforms the host society. Fourthly, if liberal humanist accounts of the autonomous, unitary subject are dispensed with, like intertextuality identity becomes a dynamic space of transformations; possibly chaotic, certainly not stable, identity is constantly in process. For the transcultured self Margaret Parry (2003: 102) has offered a definition which, mutatis mutandis, would serve very well for intertextuality as well:

As a working definition, the transcultured self may be described as one who . . can dwell in travel, that is, who can temporarily acculturate to the other's world, but without losing hold of the self. It is not a hybrid identity, but a being in becoming, one which is brought to a fuller recognition of itself through confrontation with difference and, simultaneously, to the sense of its own limitations. [Original emphasis]

Of such "being in becoming" Othello is the archetype in the intertext of the Englishspeaking world.

Fifthly, and most importantly for our purposes, allusion has been characterised as constituting an alien presence in a text, an alien presence which is removable from the text, not an organic part of it (Plett 1991: 9); in Riffaterre's words (1980: 110), intertextual fragments are "perceived as foreign bodies with an independent textual presence elsewhere". Mutatis mutandis once again, the foreigner or outsider is an alien presence in a given host society, a literal foreign body whose organic integration some might suspect and whose removal a few might desire. Intertextual theory even provides a terminology in which those few might seek respectability for their desire: the intertextual fragment is "an improprie-segment replacing a hypothetical proprie-segment" (Plett 1991: 9); it is improper in that it does not belong genetically to the text it has been grafted onto, but has been parented elsewhere -is of a different blood. That impropriety verges on the unethical in that the intertextual fragment does the work that a putative genetically proper element could well have done- an argument more familiar from those who accuse immigrants of stealing the work of natives. Instead of "improper", Riffaterre generally prefers the politically and ethically neutral term "ungrammatical", by which he means that perceived incompatibility between words or phrases which, in a given text, do not make literal sense but defy the reader's assumption that language is referential. Ungrammaticalities, including tropes, figures, irony, humour and intertextuality, "stem from ... the fact that the poetic verbal sequence is characterised by contradictions between a word's [or fragment's] presuppositions and its entailments" (Riffaterre 1980: 5). Ungrammaticalities are identified thanks to the reader's exercise of his linguistic competence on the "first, heuristic reading ... where the first interpretation takes place, since it is during this reading that meaning is apprehended" (1980: 5). They are ironed out or made grammatical thanks to the reader's literary competence . . . this is the reader's familiarity with the descriptive systems, with themes, with his society's mythologies, and above al with other texts. Wherever there are gaps or compressions in the text- such as incomplete descriptions, or allusions, or quotations -it is this literary competence alone that will enable the reader to respond properly.

Since intertextuality is both semiotic process and socio-cultural condition, the twin notions of "ungrammaticality" and "impropriety" are not in conflict but actually comple- 
ment each other; in fact on one occasion Riffaterre fuses the two in the felicitous expression "deviant phraseology".

Now, together with accent, ungrammaticality is one offence committed by foreign users of a host language on a scale of linguistic abuses at the other end of which is that "void or baroque speech", "absolute in its formalism, excessive in its sophistication" (Kristeva 1991: 20-21), which the "Othello music" epitomises, which Phillips mimics in his "Othello" fragments, and whose absence of past and social connections (Kristeva 1984: 20 ) is betrayed by the twin void graphemes "Othello" shares with orotundity. ${ }^{9}$ But there is more to intertextual ungrammatically in relation to foreign bodies than incorrect, improper language use, as the next section will show.

\section{DEVIANT PHRASING IN THE NATURE OF BLOOD}

The Nature of Blood abounds with ungrammaticality and impropriety on both macroand microstructural levels. To some readers, the most egregious example of impropriety on the macrostructural level is Phillips's supreme effrontery/self-confidence in tackling the holocaust. Two questions arise: 1) What might Phillips add to the writings of Ann Frank, one of his pre-texts, or, say, Primo Levi's Si questo è un uomo, which remains at once the most humane, moving and profound treatment of such abominable matter? 2) Is there not something improper in a writer engaging with an issue which he is not experientially qualified to address? These are sensitive matters, which expose to the charge of prudishness those who would accuse Phillips of prurience..$^{10}$ But I think there is some sort of criterion of taste which silently imposes an unspecified moratorium on fictional re-creations of appalling acts or events by third parties, re-creations which do not pass the test of authenticity. Phillips may well be sincere -there may well be that "congruence between [his] feeling and avowal" which Trilling (1974: 7) defined as sincerity- but there is a shortfall of authenticity, not now in Trilling's ethico-aesthetic sense (1974: 11, 92-105), but in the epistemological sense of empirically proven. This is surely the very least that one should require of so-called "trauma fiction", except perhaps that such fiction be not fictional at all. There are areas of human experience which, if set down on paper, should be prefaced with Levi's (1987: 16) own disclaimer of fictional content: "It seems to me unnecessary to add that none of the facts are invented". However, since such misgivings about Phillips's subject-matter may owe more to unenlightened squeamishness on the part of some critics than to impropriety on his, let us move on to a more objective case of ungrammaticality.

One needs to be a pretty self-assured writer in order to use Shakespeare as a pre-text which, prima facie, Phillips does in his "Othello" fragments. Shakespeare is one of those rare writers whose intertextual practice causes his quotation-texts to supersede, even to efface and obliterate, their pre-texts. But Phillips seems to wish to re-route the reader's

\footnotetext{
9 See Sell (2000: 191-2) for similar characterisations of their own English by Indian poets Keki Darwallah and Kamala Das. For more thoughts on the "loquacious and 'liberated' foreigner", see Kristeva (1991: 31-2).

10 Hilary Mantel has written, "it is indecent to lay claim to other people's suffering: it is a colonial impulse, dressed up as altruism"; James Shapiro would charge Mantel with "literary tribalism" (Shapiro and Mantel both cited in Ledent [2002: 150-51]). Compare also Ozick (1997: 76) on Phillips's Eva: "an unholy speculation [that] tampers with history, with reality, with deadly truth" another "misappropriation".
} 
intertextual sleuthing away from Shakespeare to the pre-text which provided Shakespeare with the germ for his tragedy. This would appear to be the point of his ungrammatically inserted, paragraph-length, encyclopaedia-style explanation of "Othello":

OTHELLO: A play by William Shakespeare. Probably written between 1602 and 1604, and first performed in 1604. The principal source for the play is Giraldi Cinthio's Hecatommithi, a collection of Italian stories first published in Venice in $1566,{ }^{11}$ and used by a number of Elizabethan and Jacobean dramatists as source material for their plots. Out of one key sentence in Cinthio's story, Shakespeare wrote the early scenes of the play.

It happened that a Virtuous Lady of wondrous beauty called Disdemona, impelled not by female appetite but by the Moor's Good qualities, fell in love with him, and he, vanquished by the Lady's beauty and noble mind, likewise was enamoured of her. (Phillips 1998: 166-7)

There are several comments to be made. Note, first, how this is Phillips's only -and belated-mention of Othello; the Moor of his "Othello" fragment remains anonymous, as he is in Cinthio, this anonymity serving as the prime indication that Phillips wants to "unfix〈es〉 Othello's Shakespearean moorings" (Armstrong 2002) and to restore his original, nonintertextual condition. Those moorings are additionally unfixed by placing Shakespeare as only one of many who used Cinthio's collection. Secondly, Phillips himself only reworks the Othello material covered by Shakespeare in the first scenes of the play, to be precise, as far as his landing on Cyprus (2.1): the whole tragic unfolding of events which is the matter of acts 2 to 5 is ignored in The Nature of Blood, although it can never fail to tinge the reader's experience of Phillips's "Othello" fragment. ${ }^{12}$ Now Shakespeare's tragic unfolding of events is a marvellous amplification of Cinthio's artless and perfunctory story; yet in this passage, Phillips suggests that the greater literary achievement is Cinthio's, capable of capturing in "one key sentence" an essential quid which Shakespeare watered down into one act and a bit. It is all as if Phillips wishes to disinherit Shakespeare of his pre-textual monopoly on the "Othello" story by erasing the Moor's name and excising the tragedy. To the reader whose first instinct is to read Phillips's macrostructurally ungrammatical "Othello" fragment in relation to Shakespeare, Phillips's intertextual procedure is, then, markedly ungrammatical on the microstructural level too. His "Othello" quite simply isn't Shakespeare's. Just as the (achieved) purpose of the "Portabuffole" fragment is to find a Jew of Venice who is free of any Shakespearean taint, so the "Othello" fragment attempts to circumvent the intertextual pressure exerted by the Moor's tragedy on subsequent representations of race.

As mentioned above, it is true that, like Shakespeare's, Phillips's "Othello" speaks stately, slightly over-wrought English; it is also true that Phillips's emphasis is on the arrival of his character to Venice, an experience of transcultured subjectivity entailing the abandonment of a foreign past and the uncertain embrace of a European future which is also

\footnotetext{
11 The Hecatommithi was first published in 1565 (Honigmann 1999: 368).

12 If Cyprus is the terminus ad quem for Phillips's "Othello" and the scene of the excised tragedy involving Cinthio's and Shakespeare's European Christian and Black Christian convert, it is also the terminus a quo Stephan (European Jew) is transported to Israel where he will meet Malka (black, Ethiopian Jew). If such parallelism is to be of any purpose, is the reader to suppose that, beyond the novel, Malka and Stephan too will meet a tragic end?
} 
allusively present in Shakespeare but completely absent in Cinthio. ${ }^{13}$ But the differences far outweigh the similarities. A striking case of intertextual ungrammaticality and impropriety is Phillips's (1998: 135) invention for his "Othello" of a wife and son: not only does this controvert the pre-text and generate intellectual estrangement in the reader, who either knows perfectly well that there is no wife or family in Shakespeare or, given sudden cause to doubt, starts checking in the Complete Works; but it also calls into question the moral probity of Phillips's "Othello" as suitor of the Venetian lady and, more indecorously still, of the pre-textual Othello whose romantic love for Desdemona is potentially transformed in intertextual retrospect into a cunning, unethical strategy for marrying into Venetian society. ${ }^{14}$ It is probably not Phillips's aim to cast a slur on his own character, who proffers a justification he knows will not free him of his wife's "harsh judgement" (135); more likely he wishes to represent the realpolitik of transcultural survival on the one hand and to emphasise the emotive weight of a native past on the other. ${ }^{15}$ However, reading Phillips's "Othello" against its Shakespearean pre-text is a discomfiting experience not only intellectually but also emotionally, as the moral indignation aroused by the intertextual impropriety may bring some readers close to repudiating both Phillips's "Othello" and, more perniciously, its dimly recalled Shakespearean original.

In addition to estranging us from Shakespeare in his attempts to rewrite the nature of transcultural subjectivity, Phillips also uses allusion to give his "Othello" a more authentic alien identity by positioning him within a non-canonical pre-text. ${ }^{16}$ "Othello" recalls how "During my return journey [from the house of the lady's father] it began to snow. Tiny white flakes spun down from the dark sky and lightly dusted the gondola with a thin salty layer" (128). As Galván (2004) has suggested, the allusion in this passage is to one of the works extracted in Phillips's Extravagant Strangers, namely, The Interesting Narrative of the Life of Olaudah Equiano, or Gustavus Vasa the African, written by himself, first published in 1789. Among other "English wonders" Equiano remembers how "[o]ne morning when I got upon deck, I saw it covered all over with the snow that fell over-night: as I had never seen any thing of the kind before, I thought it was salt" (Phillips 1997: 14). The strong resemblance between the two passages (an arrival, a waterborne vessel, snow like salt) makes it reasonable to deduce that Phillips wishes to rewire Othello's allusive frame of reference so that the current flows through it of a more authentically alien identity, one which relies on metaphor to make cognitive sense of snow.

But constitutive of a more patent and unbalancing allusive excursus into ethnic alterity are the two unseasonable and anonymous outbursts upbraiding Phillips's "Othello"

\footnotetext{
13 Othello's past is present, however partially and doctored, in his famous accounts of "the battles, sieges, fortunes / That I have passed" and of the Aleppo incident, and in his mention of his mother and father (1.3.129ff, 5.2.350ff, 3.4.57ff) (Honigmann 1999).

14 Admittedly, this is a possibility latent in Shakespeare's text; but it is by no means mandatory.

15 Also, Gerry and Stephan (temporarily and permanently, respectively) abandon wives and children at some point or other, a case of intratextual parallelism which may mean to underscore the shared humanity of all mankind, whether English, Jewish or black African. Calling a British WW2 serviceman Gerry, one of the less indecorous sobriquets for the German foe, is a further case of allusive impropriety.

16 Of course, "transcultural subjectivity" here is shorthand for the particular kind of Afro-American subjectivity immersed in an alien society which Phillips's "Othello" seems to evince. Phillips's "Othello" is not emblematic of all kinds of transcultural subjectivity.
} 
in the second person. Regardless of whether this is the voice of a friend back home or of "Othello" debating with his own conscience, the marked ungrammaticality splinters the cool tranquillity of the whole Venetian episode and brings "Othello"'s alterity rudely to the surface. The ungrammaticality is chiefly a matter of chronology as a whole series of allusions render synchronous a variety of pre-texts, both literary and cultural, from diverse times and places. So Uncle Tom, an American football wide-receiver, Louis Armstrong ("Satchmo") and Jim Crow are all thrown in, together with a Yoruba saying about the perils of forgetting one's past (181-183). If on the mimetic level the reader's estrangement from Shakespeare's Othello could not be more extreme, on the semiotic level the effect of this head-spinning ungrammaticality is to shove the reader into the same sort of cognitive bewilderment a foreign subject might experience on being himself plunged into an alien culture.

\section{CONCLUSIONS: INTERTEXTUALITY, METAPHOR AND ALTERITY}

So the effect of Phillips's intertextual procedure is twofold. Firstly, by introducing allusive references to Equiano and totemic figures of racial alterity on the one hand and by deconstructing the Shakespearean archetype of ethnic alterity on the other, "Othello" is defamiliarised and stands before the reader as a more foreign body, more deviant from our discursively constructed schemata of alterity than perhaps we might wish. Secondly, by disorienting the reader in regard of the Shakespearean pre-text, Phillips's deviant phraseology generates the very cognitive uncertainty which arises upon immersion in an alien culture with its particular set of members' resources, including intertextual references to recognised pre-texts; ${ }^{17}$ as a consequence of this temporary estrangement from his own culture, the reader is made to share with "Othello" the experience of alterity proper to the transcultural subject, at once representative of an alien sign system and, in him or herself, a microcosm of that sign system, when translated or transposed from his homeland to another. And that is precisely the sort of accomplishment which, for Derrida, lay beyond the rhetorical and persuasive reach of literature. Yet it is an accomplishment implicit in Kristevan notions of intertextuality as embodying otherness and offering a "modality of transformation" (Kristeva 1984: 89) both of the individual and, like other foreign bodies, of the text of society at large. Intertextuality may then transpose us, much as metaphor may translate us, into a new world and make culture gaps bridgeable.

The parallel with metaphor is by no means gratuitous. In so far as intertextuality's deviant phraseology registers, in its ungrammaticality, on the intellect (which it bewilders) and, in its impropriety, on the senses (which it stimulates), it has a two-fold effect akin to that of metaphor which, since time immemorial addressed both reason and emotions, offering enhanced cognition with a dividend of pleasure (or distaste). At this point the conceptual terrain we are covering is criss-crossed with a tangle of metaphorical and semantic connections. For metaphor as translation translates us from our world to the world of the other, from known topic to unknown vehicle; as a means to cognition, it depends, crucially, on traversing the different domains of topic and vehicle. If we assent to the proposed relationship between topic and vehicle, we admit their common ground and thereby open up pores in

17 I borrow the term “members' resources” from Fairclough (1989: 11 and passim). 
the membrane dividing topic and vehicle domains. By mapping or transposing one domain onto the other, we can "see new correspondences or indeed attribute new structures or properties to objects, concepts and situations" (Semino 1997: 203). This process of translation is analogous to intertextuality which, for Kristeva, is a transposition of one sign system into another. The first effect of deviant phraseology is puzzlement which, as we observed above, may trigger automatic rejection of the improper or may more positively stimulate curiosity in the reader and lead him to make sense of the apparently ungrammatical. The disorientation produced by deviant phraseology is therefore, like metaphor, a rhetorical strategy which either pushes us to repudiate the intruding intertextual foreign body (in the present case Phillips's "Othello") or steers us along the path of further learning as contexts and cultures are found which enable the deviancies to be ironed out. Much as we will try to find out in which pre-texts the allusive references becomes grammatical and proper, so we may attempt to become familiar with the social, cultural, racial and ethnic contexts where the foreign body encountered in the text is not a foreign body and, more optimistically, to build a new context where estranging factors are removed all together. ${ }^{18}$

Caryl Phillips's intertextual procedure in The Nature of Blood is therefore an invitation to create new cognitive domains where alterity becomes familiarity and to entertain the possibility of constructing new cultural domains where neither same nor other are cast as deviant. Far from being merely an exercise in postmodern cut and paste or a conventional subaltern challenge to a hegemonic cultural text, the deviant phrasing of Phillips's "Othe1lo" fragments suggests that the cognitive challenge posed by intertextuality may become an exercise in intercultural empathy which, if carried out with any degree of success, will equip us better for life in a multicultural or cosmopolitan society. More than mere subversion, this mimetic intertextuality is pedagogical; its identification in Phillip's rendering of "Othello" could lead to fruitful reconsiderations of his "Shylock" and "Anne Frank" in the same novel, as well as, naturally, to all fictional representations of transcultural subjectivity.

\section{REFERENCES}

Armstrong, A. 2002. "Bloody History! Exploring a Capacity for Revision. Restaging History in Wilson Harris's Jonestown and Caryl Phillips' The Nature of Blood". Jouvert 6.3. http://social.chass.ncsu.edu/jouvert/v613/armstr.htm (28 February 2008).

Barthes, R. 1976. The Pleasure of the Text. Trans. R. Miller. New York: Hill and Wang. 1988. "The Death of the Author". Twentieth Century Literary Theory. Ed. K. M. Newton. London: Macmillan. 154-57.

BeLl, R. C. 1991. "Worlds Within: An Interview with Caryl Phillips”. Callaloo 14: 578-606,

DerridA, J. 1978. Writing and Difference. Trans. A. Blass. London: Athlone Press.

18 For a discussion of metaphor and its potential to enable transcultural communication and knowledge, see Sell (2007: 2-15). 
DörIng, T. 2002. Caribbean English Passages: Intertextuality in a Postcolonial Tradition. London: Routledge.

FAirclough, N. 1989. Language and Power. London: Longman.

Galván, F. 2004. "Between Othello and Equiano: Caryl Phillips' Subversive Rewritings." Refracting the Canon in Contemporary English Literature and Film. Eds. S. ONEGA and C. GutLEBEn. Amsterdam: Rodopi.

Honigmann, E. A. J., ed., 1999. Othello. The Arden Shakespeare. Third Series. London: Nelson.

Hutcheon, L. 1991. "The Politics of Postmodern Parody”. Intertextuality. Ed. H. F. Plett. Berlin: Walter de Gruyter. 225-36.

KLoos, W., ed. 1998. Across the Lines: Intertextuality and Transcultural Communication. Amsterdam: Rodopi.

KristeVA, J. 1984. Desire in Language: A Semiotic Approach to Literature and Art. Ed. L. Roudiez. Trans. T. Gora, A. Jardine and L. Roudiez. Oxford: Blackwell. 1991. Strangers to Ourselves. Trans. L.S. Roudiez. New York: Columbia University Press.

Ledent, B. 2002. Caryl Phillips. Manchester: Manchester University Press.

LEVI, P. 1987. If This is a Man and The Truce. Trans. S. Woolf. London: Abacus/Sphere.

Nielsen, A.L. 1994. Writing between the Lines: Race and Intertextuality. Athens: University of Georgia Press.

Ozick, C. 1997. "Who Owns Anne Frank?” New Yorker, 6 October. 76.

Parry, M. 2003. "Transcultured Selves Under Scrutiny: W(h)ither Languages?" Language and Intercultural Communication 3.2 (2003): 101-107.

PhILlIPS, C., ed. 1997. Extravagant Strangers: A Literature of Belonging. London: Faber. . 1998. The Nature of Blood. London: Faber and Faber.

Plett, H. F. 1991. "Intertextualities". Intertextuality. Ed. H. F. Plett. Berlin: Walter de Gruyter. 3-29.

Riffaterre, M. 1980. The Semiotics of Poetry. London: Methuen.

Roudiez, L. 1984. "Introduction to J. Kristeva". Desire in Language: A Semiotic Approach to Literature and Art. Ed. L. Roudiez. Trans. T. Gora, A. Jardine and L. Roudiez. Oxford: Blackwell.

Sell, J. P. A. 2000. "The Nabob of Bhanipur comes of age: a study of a fictional icon and its post-colonial afterlife." Estudios Ingleses de la Universidad Complutense 8: 175-99.

.2004. "Venetian Masks: Intercultural Allusion, Transcultural Identity, and Two Othellos". Atlantis 24. 1: 73-86. 
2007. “A Metaphorical Basis for Transcultural Narrative," Language and Intercultural Communication 7.1: 2-15.

Semino, E. 1997. Language and World Creation in Poems and Other Texts. London, Longman.

Trilling, L. 1974. Sincerity and Authenticity. London: Oxford University Press. 